\title{
FOTOGRAFICKÁ P̌̌ÍLOHA
}

\section{Všední a sváteční chvíle za socialismu}

\author{
Karel CudLÍn, K vydÁNí PŘIPRAVIl Bohuslav Šalanda
}

\section{Everyday and Holiday Moments in Socialism}

\begin{abstract}
The following annex presents a selection of documentary photography by Karel Cudlín, born in Prague, quarter Žižkov, in 1960. He can also be considered as a representative of Street Photography and a photographer of Exotic East. Black and white pictures portray everyday and holiday moments in socialism, particularly in Prague of 1980s. They show for example workers in a factory, Roma people of Žižkov, waiting for scarce goods, entertainment in Lucerna Palace, Communist celebrations, honour guard, the oath of enlistment into the basic military service. The selection from larger collection symbolically points at two perspectives on the fall of Communism (breaking events in Národní street and cutting through the barbed wires of Iron Curtain).
\end{abstract}

Keywords: documentary photography, Prague of 1980s, everyday and holiday moments

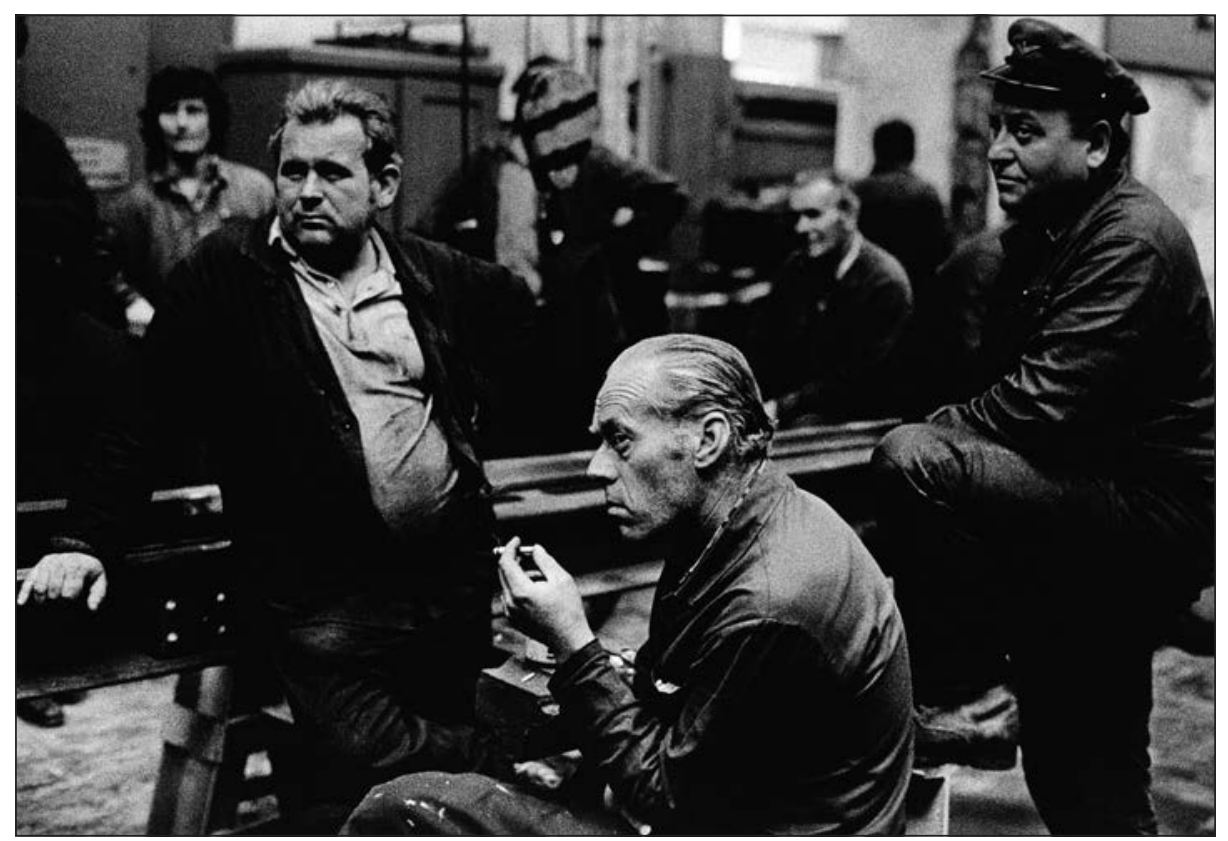

1. Praha - Karlín, dělníci v továrně Rustonka, 1979. 


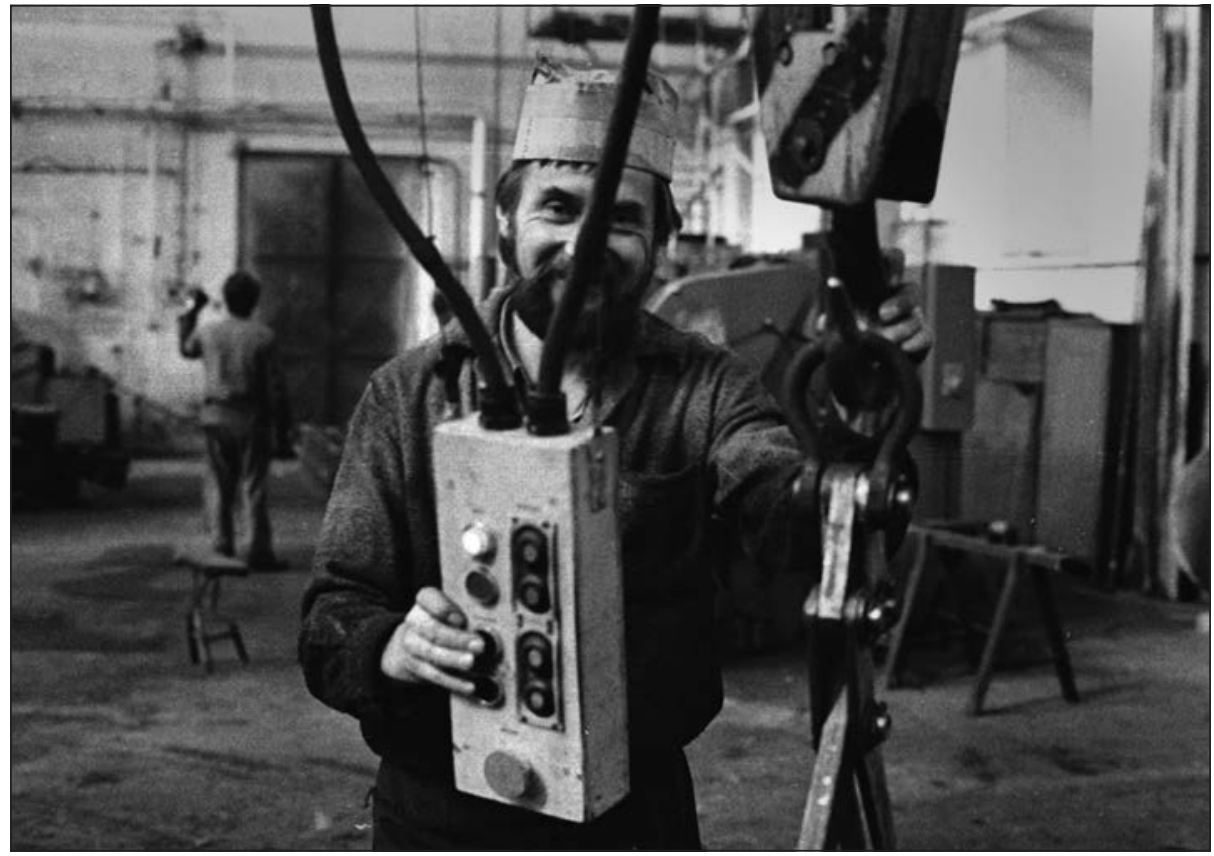

2. Praha - Karlín, dělníci v továrně Rustonka, 1979.

3. Praha - Karlín, dělníci v továrně Rustonka, 1979.

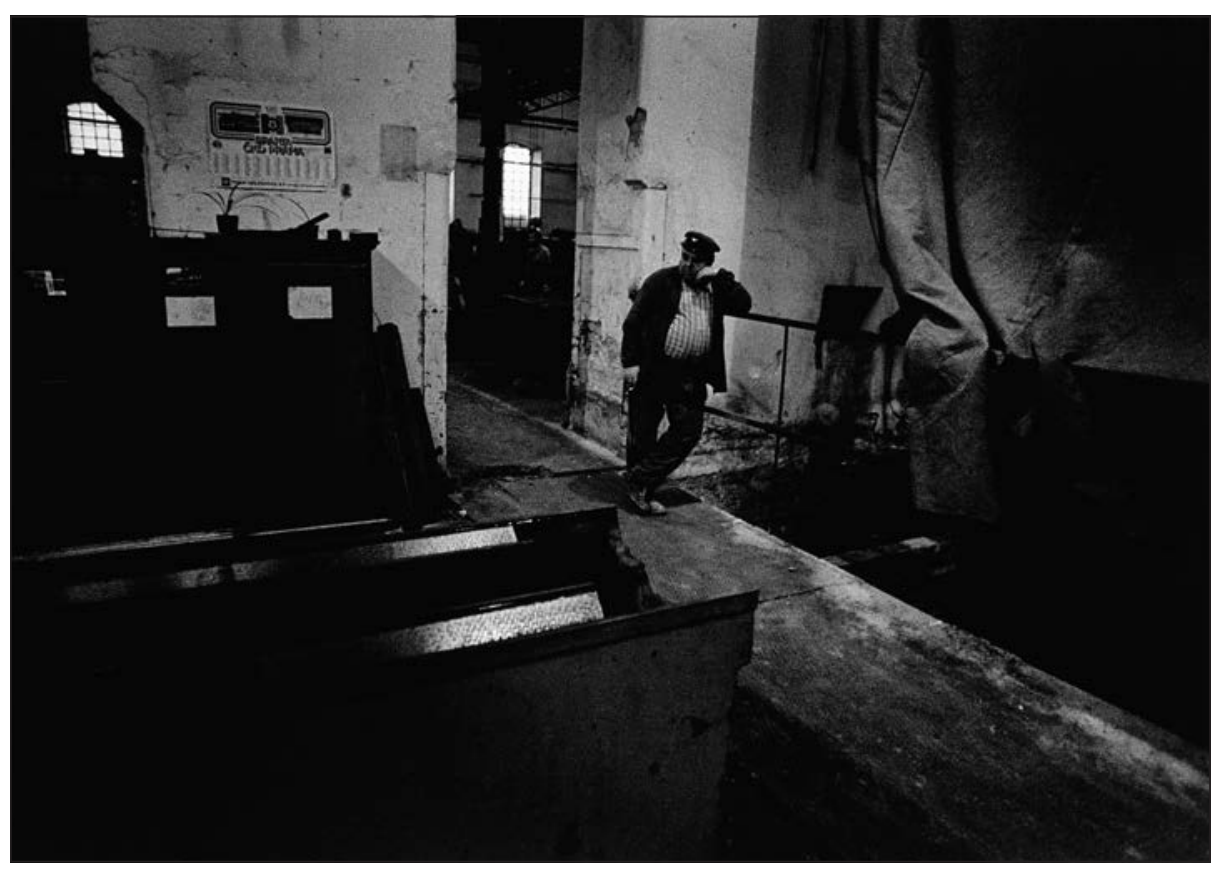




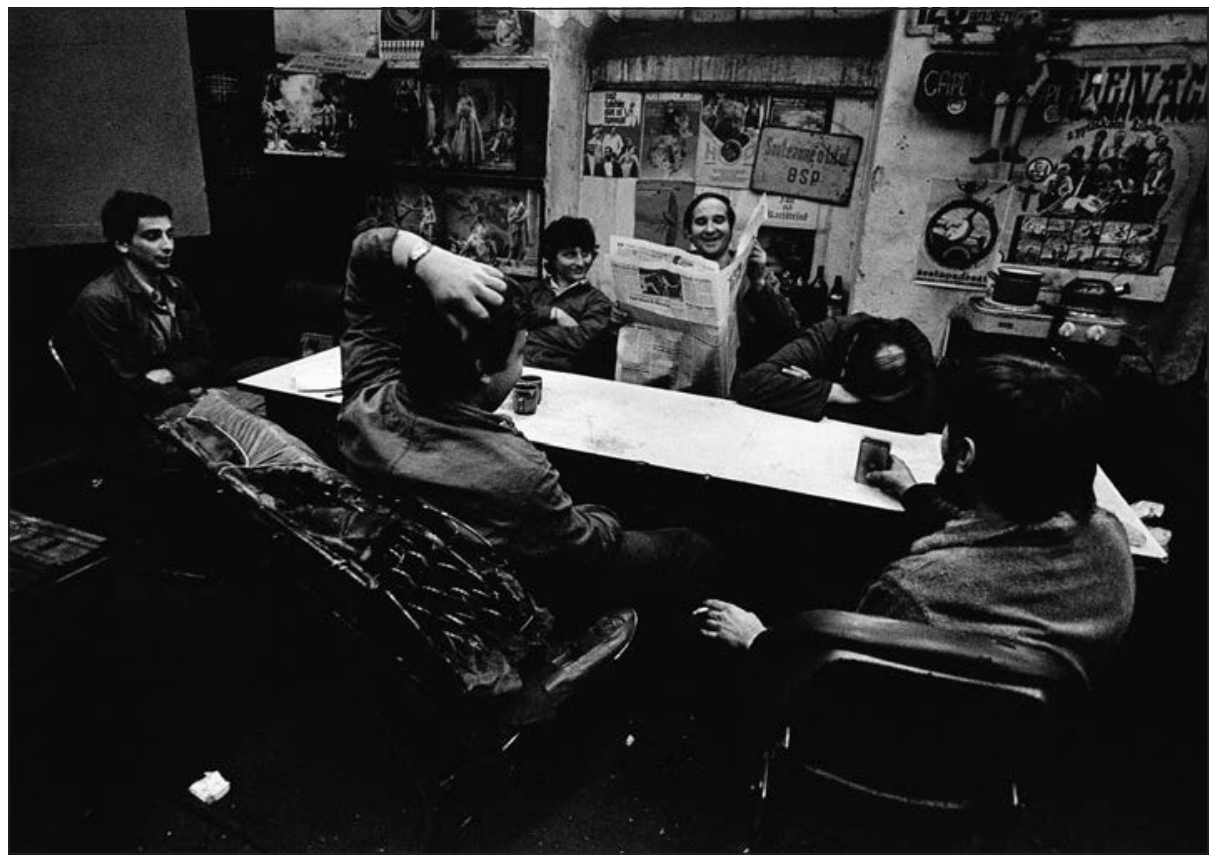

4. Praha - Karlín, dělníci v továrně Rustonka, 1979.

5. Praha, zdravotnictví, pacienti, 80. léta.

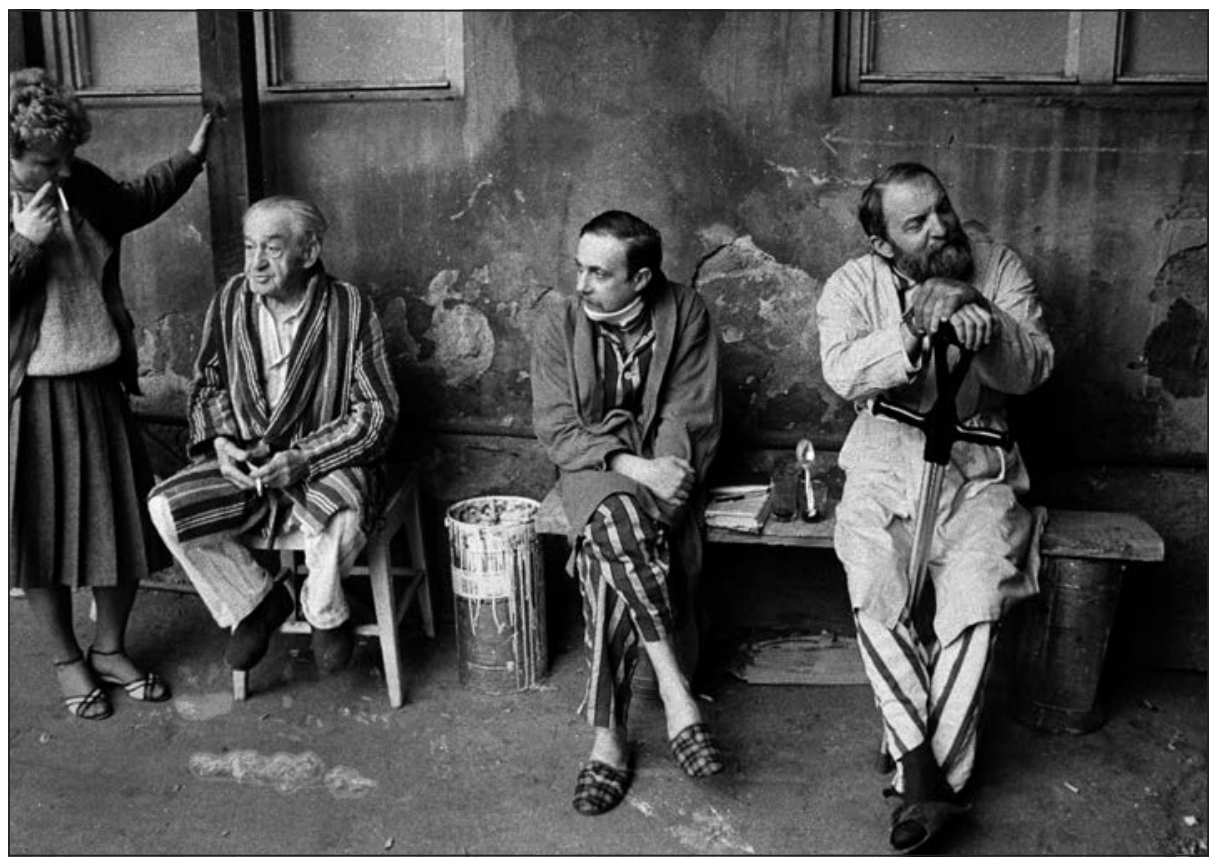




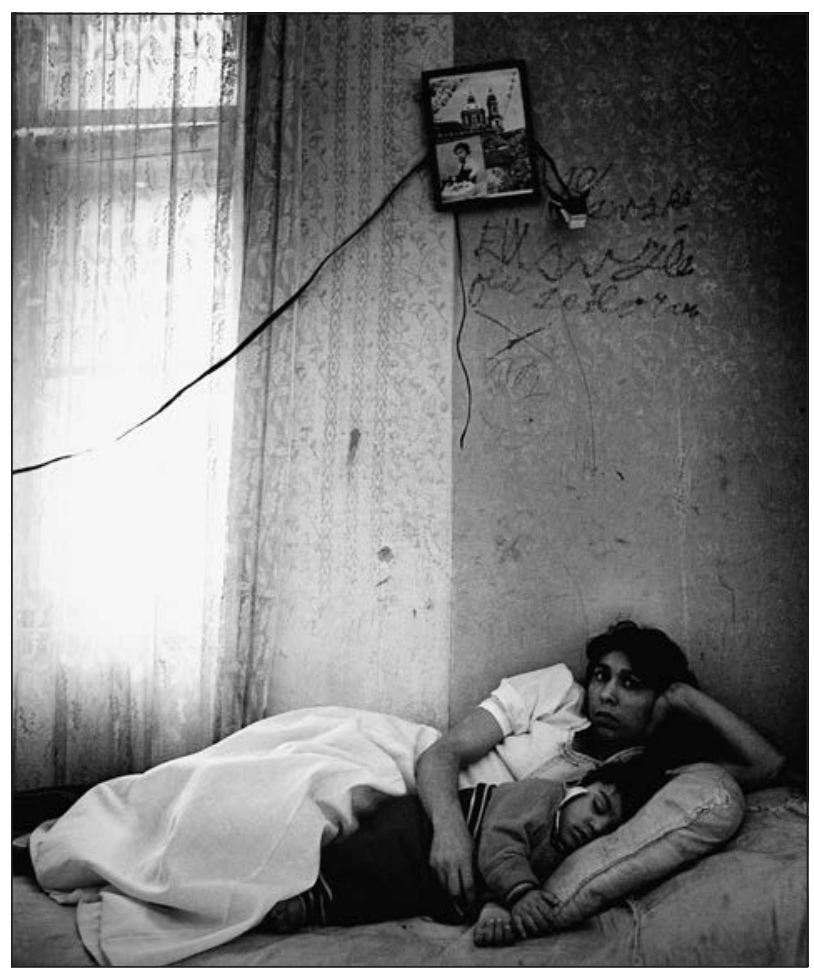

6. Praha - Žižkov, Romové, konec 70. let.

7. Praha- Žižkov,

konec 70. let.

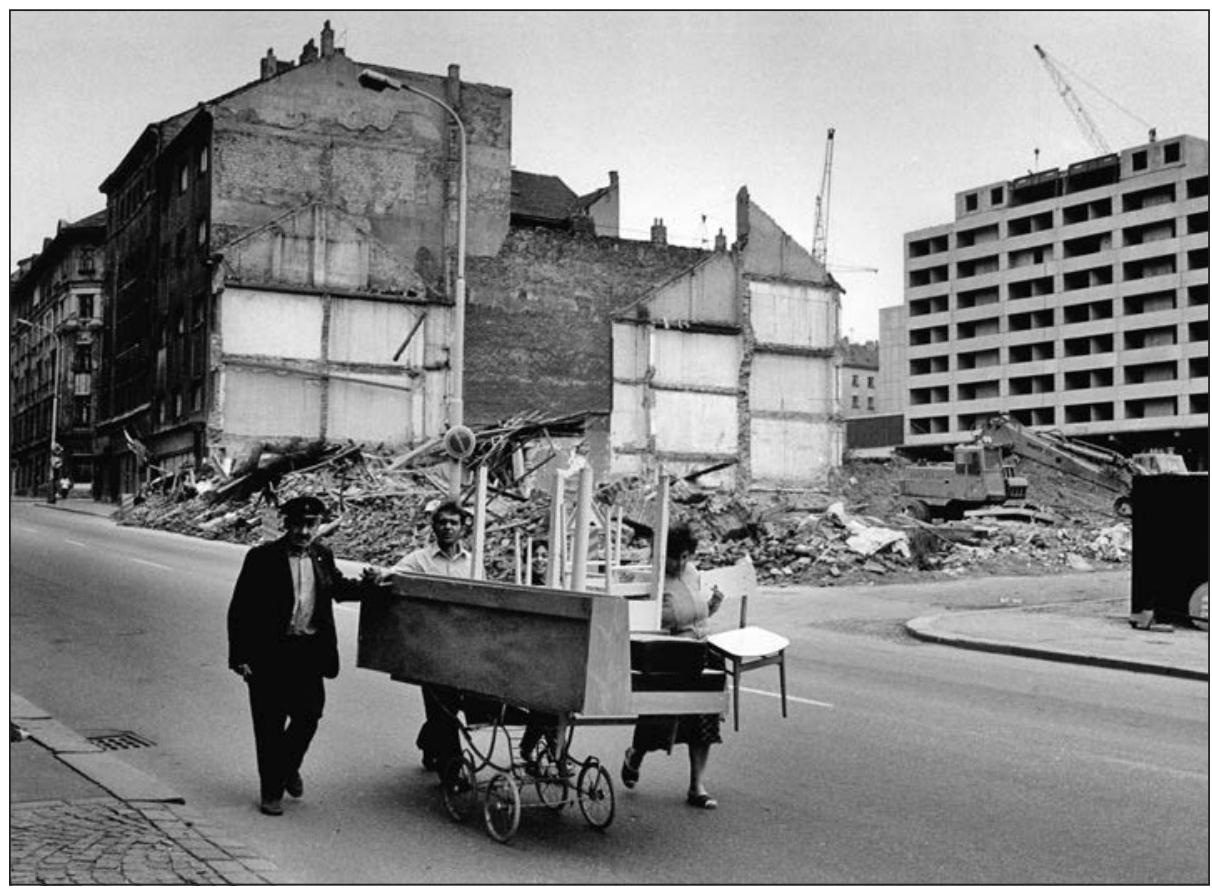




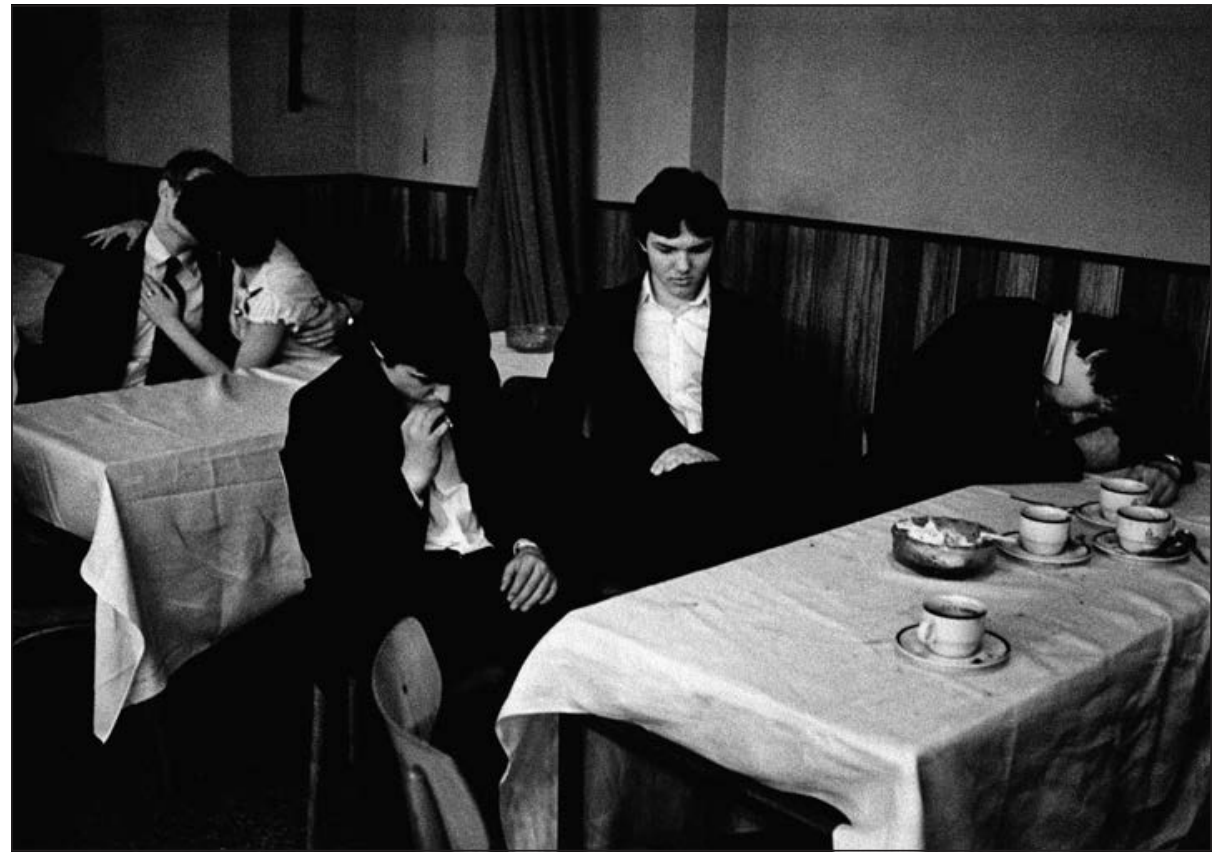

8. Praha, Lucerna, 80. léta.

9. Praha, Lucerna, 80. léta. Zpěvák Tony Ducháček.

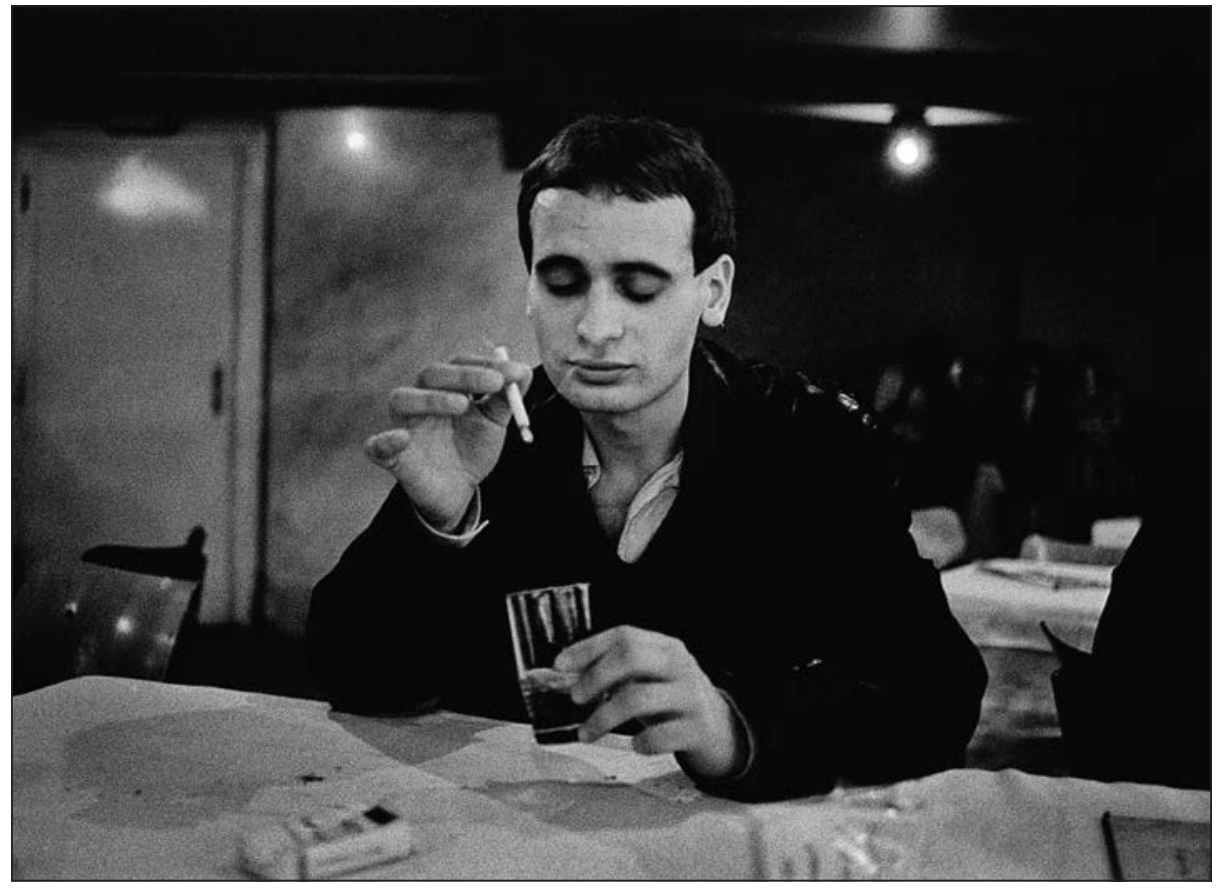




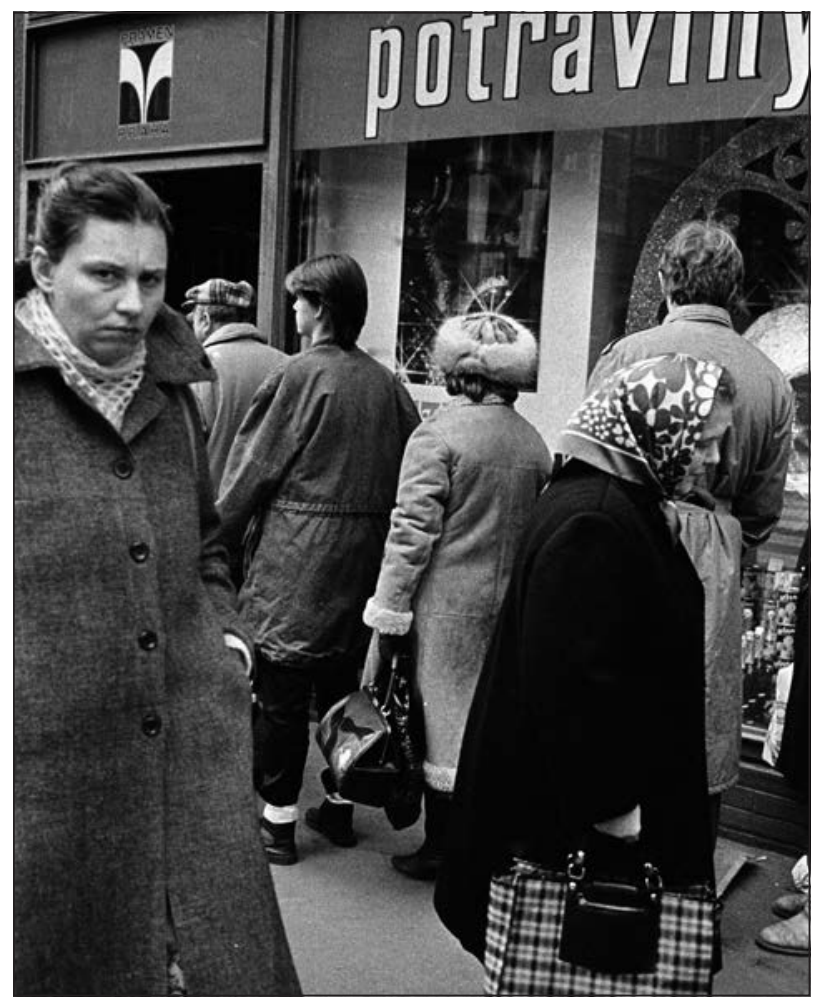

10. Praha, nákupní fronta, 80. léta.

11. Praha-Žižkov,

nákupní fronta, 80. léta.

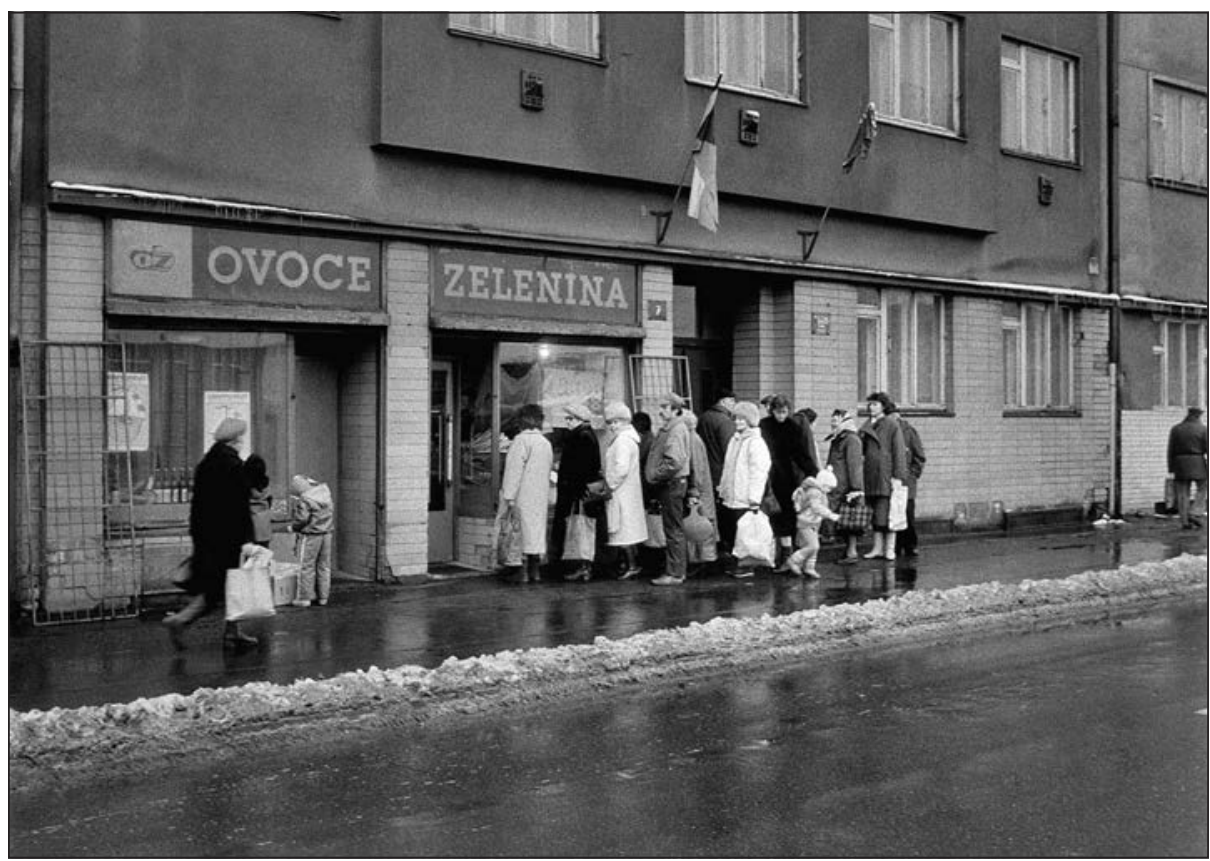




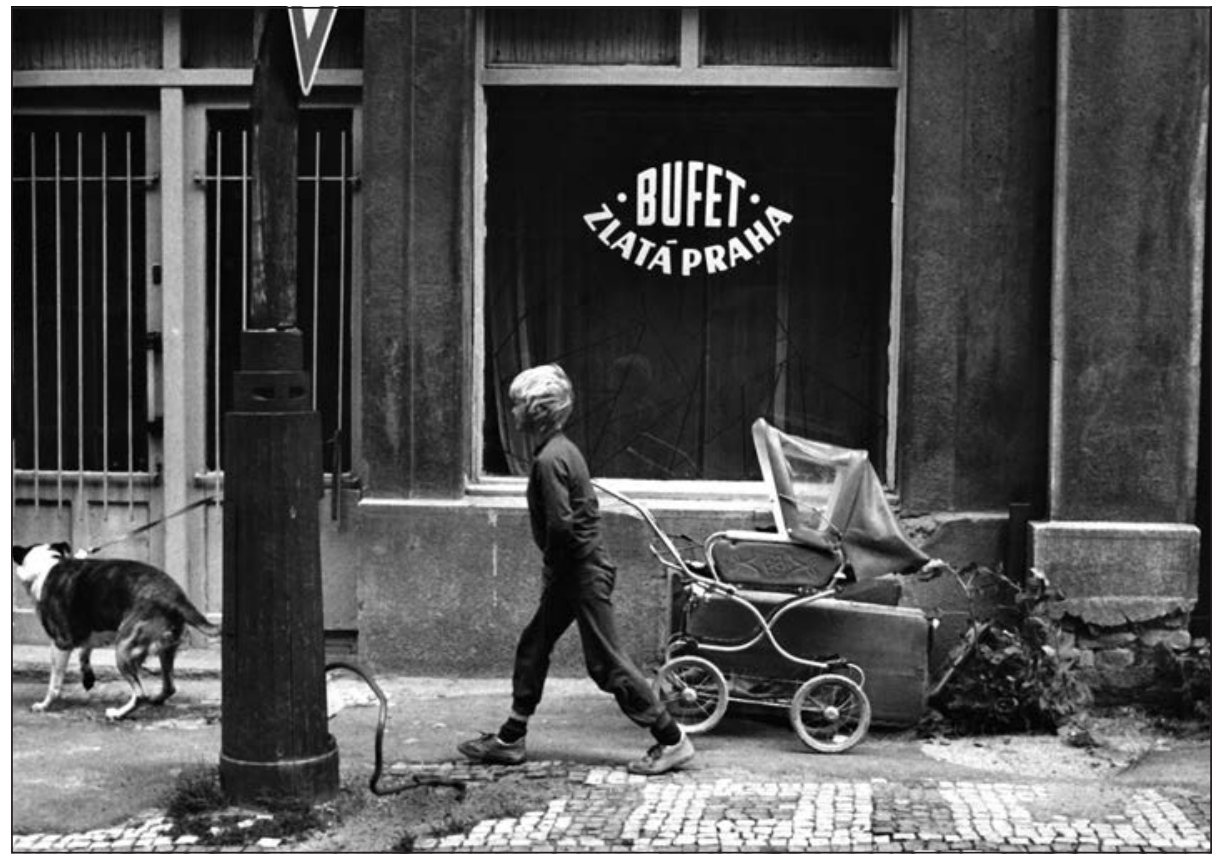

12. Praha, bufet, 80. léta.

13. Severní Čechy, bufet, 80. léta.

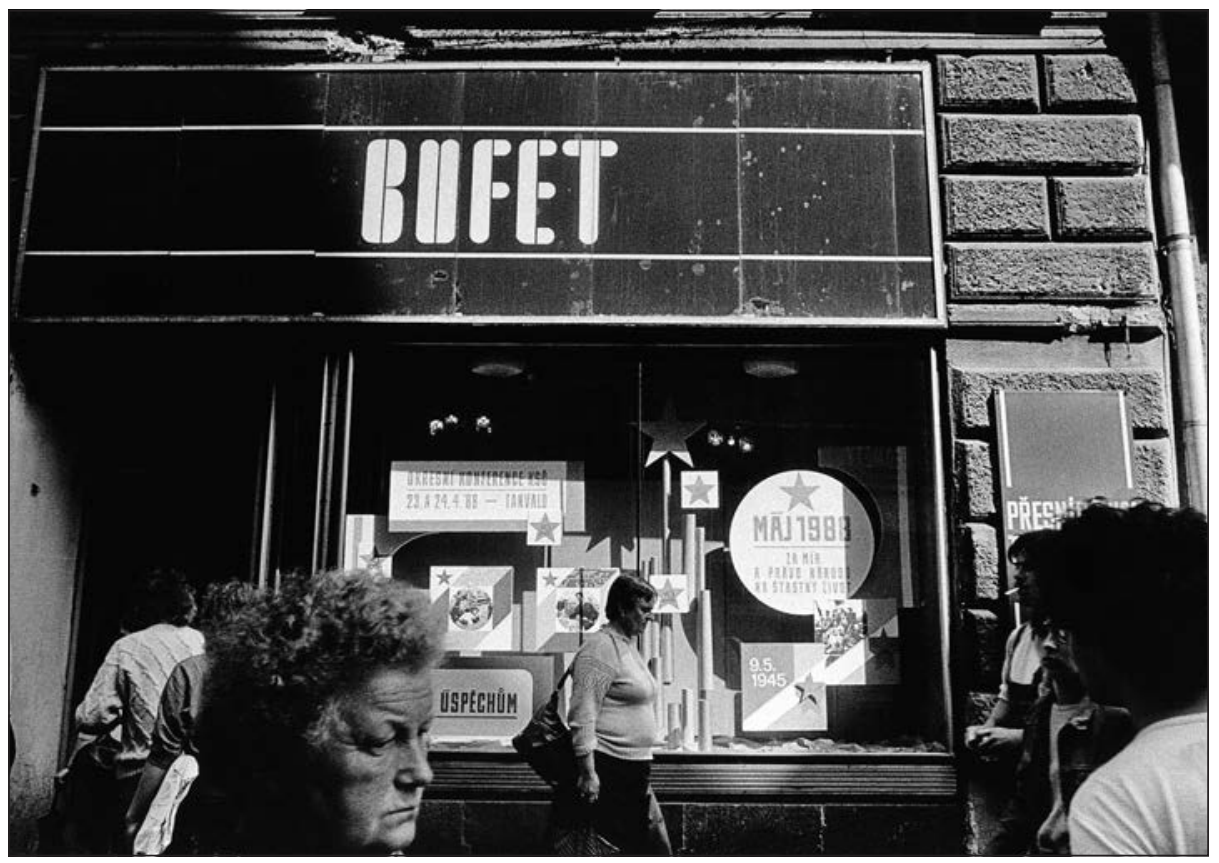




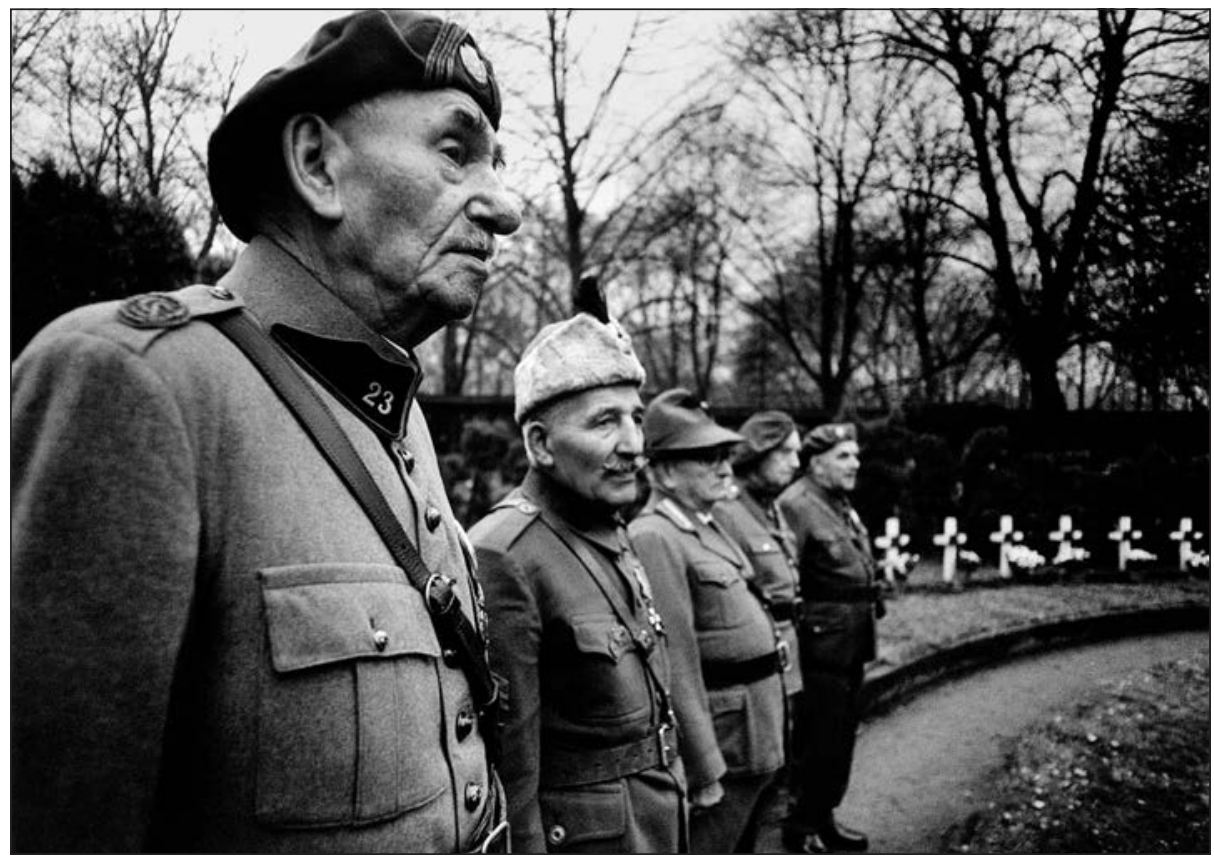

14. Praha, Olšanské hřbitovy, smuteční slavnost legionářủ 28. 10. 1984.

15. Praha, Park kultury a oddechu Julia Fuč́ka, 80. léta.

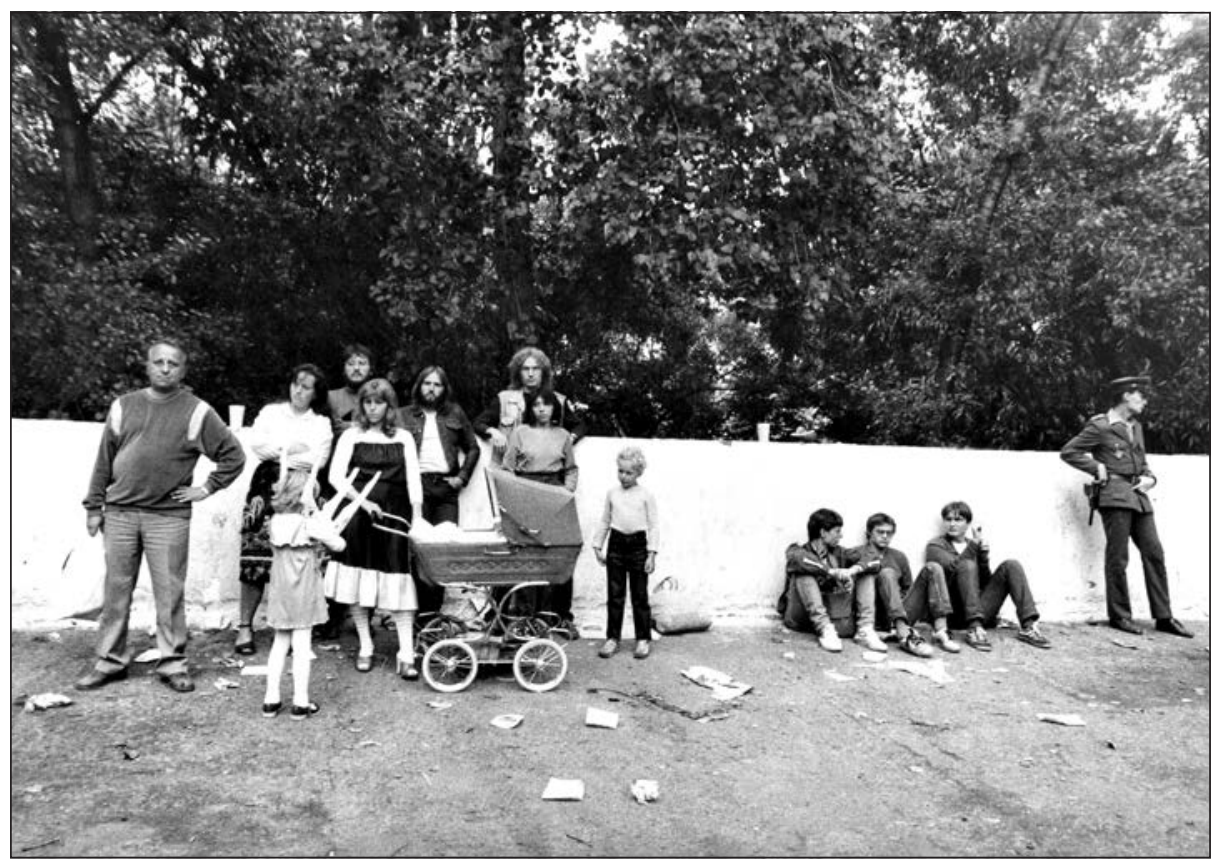




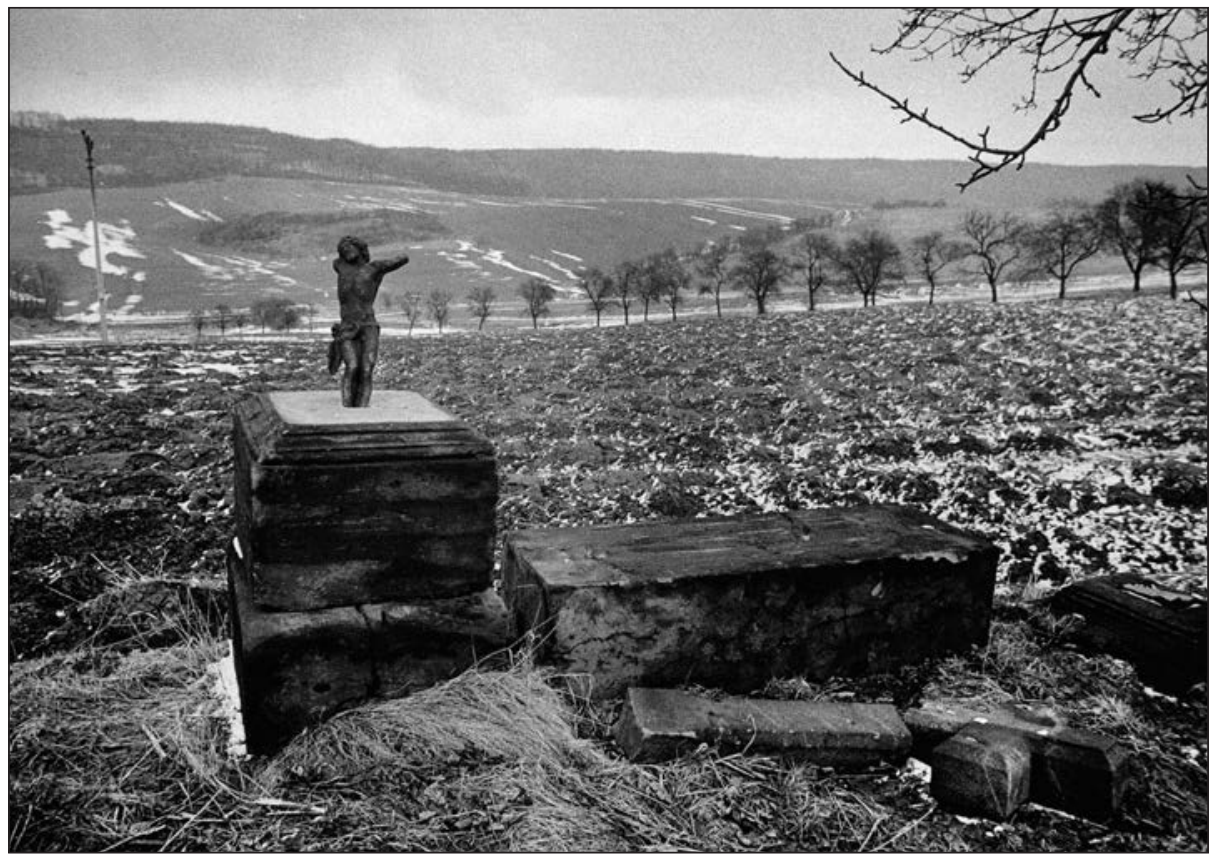

16. Západní Čechy, Sokolovsko, trosky německého hřbitova v zaniklé vesnici, 1981.

17. Komunistická propaganda, 80. léta.

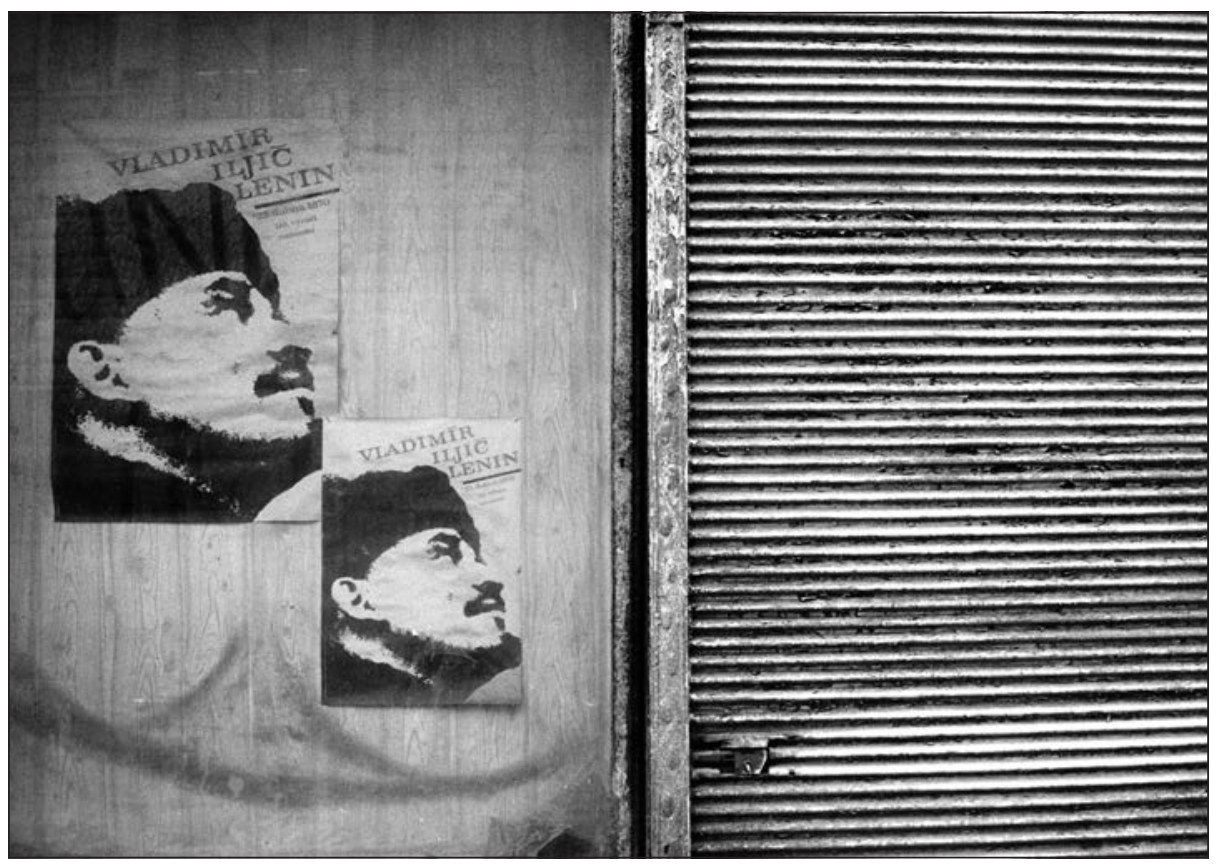




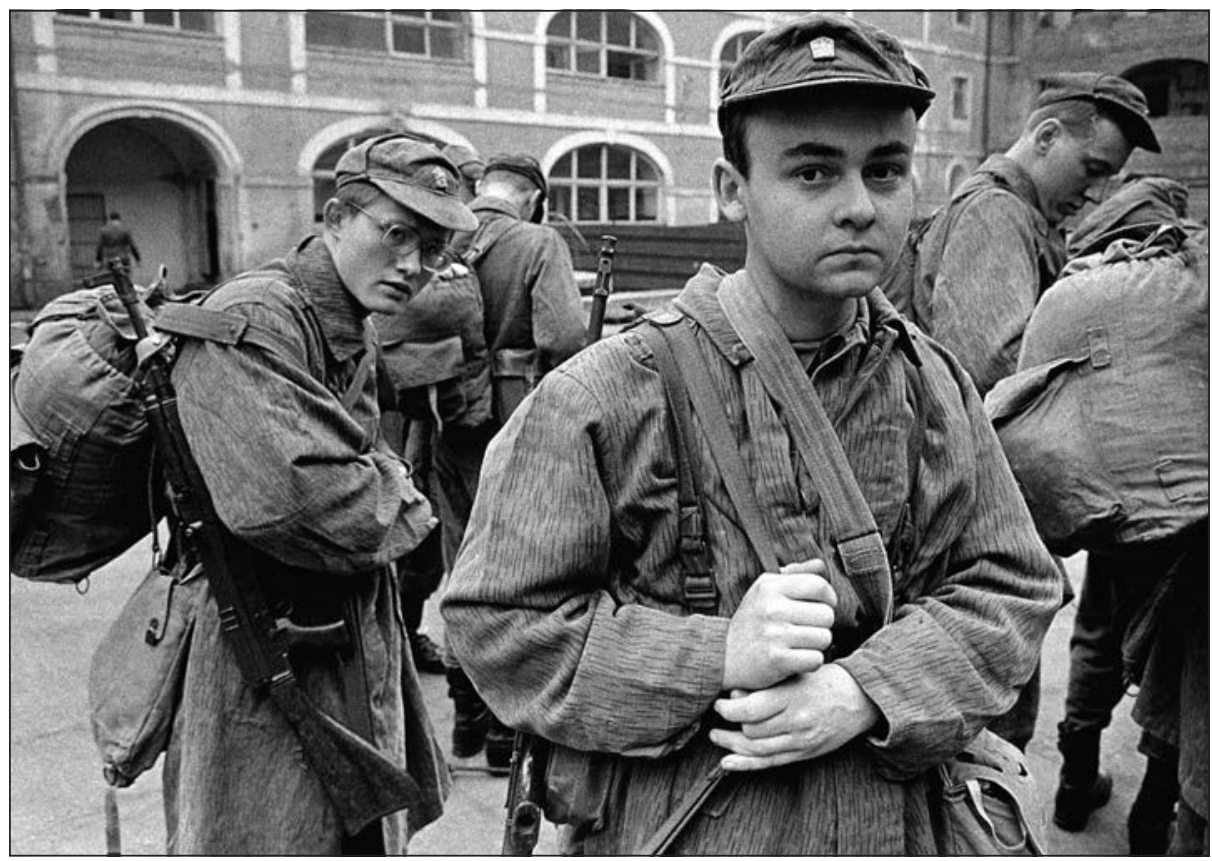

18. Západní Čechy, prìjímač, 80. léta.

19. Praha, branci, 80. léta.

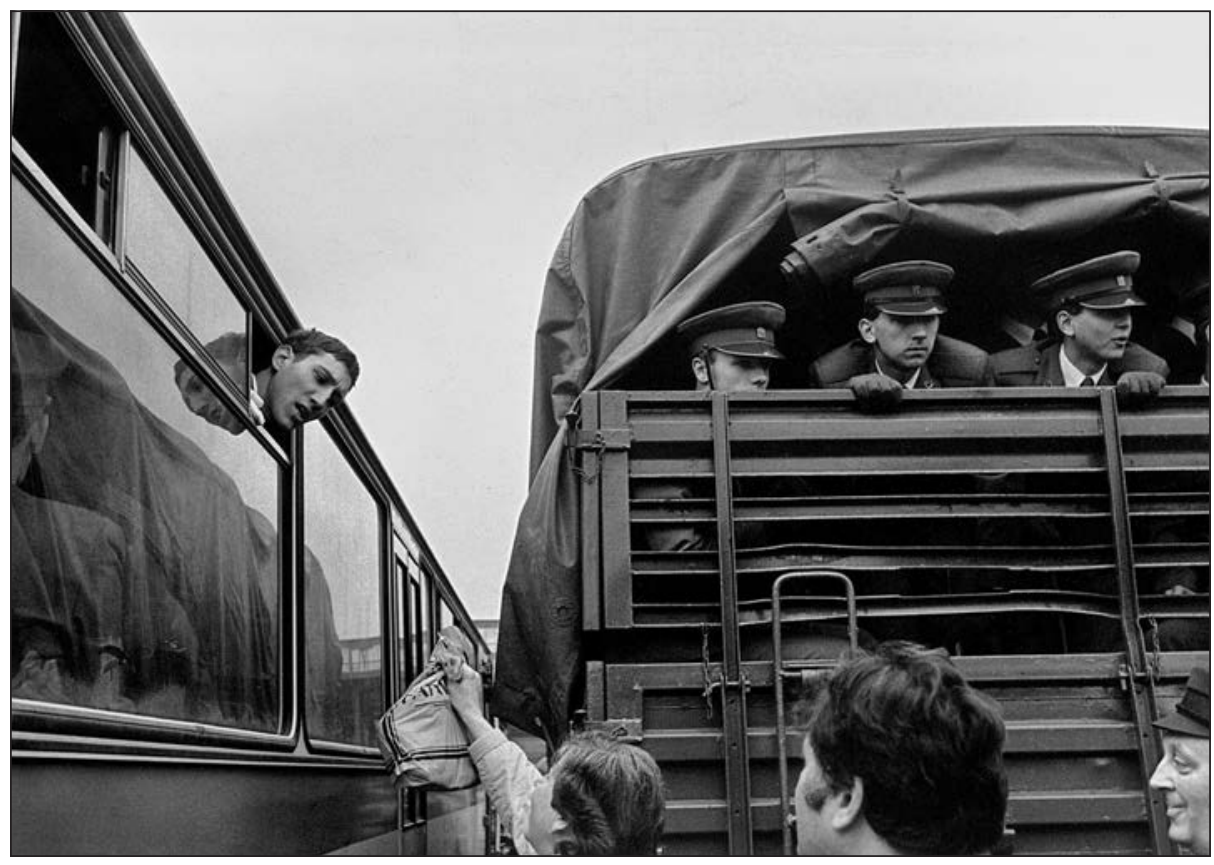




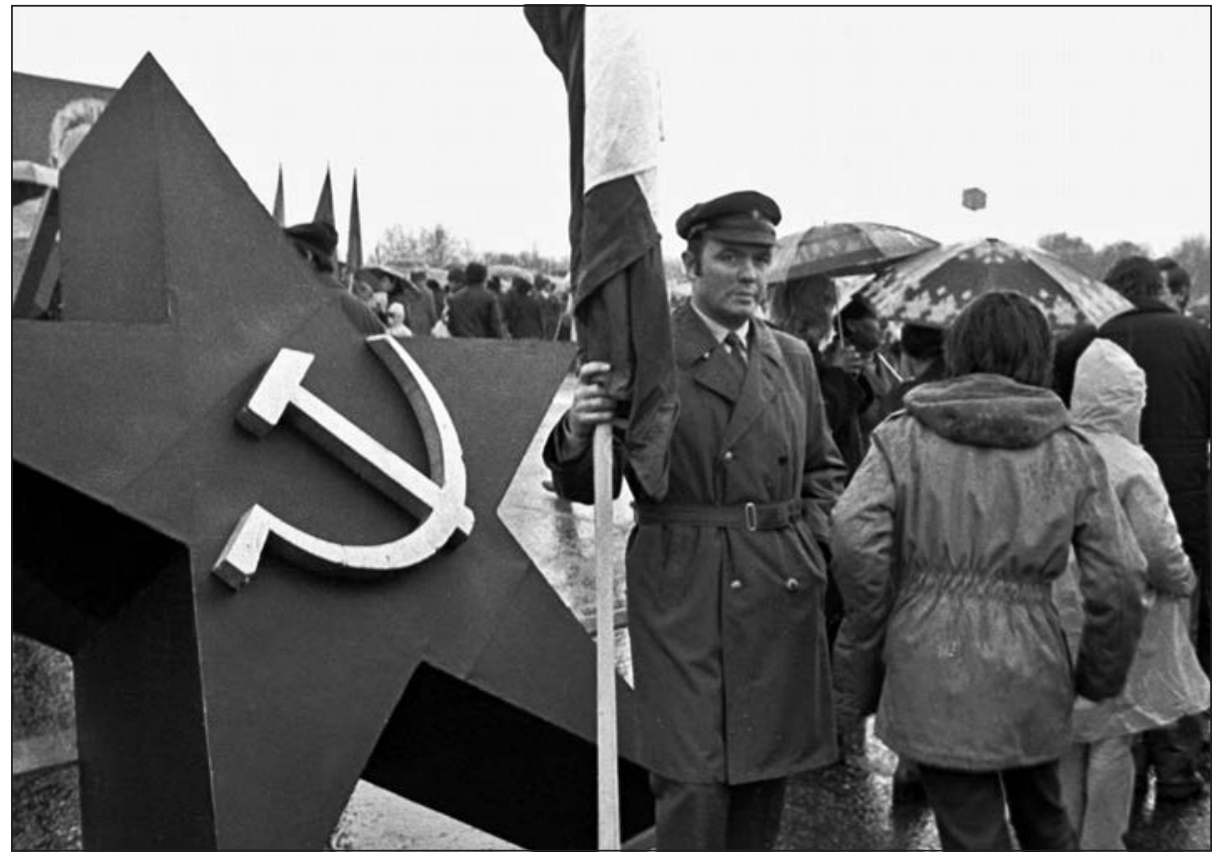

20. Praha, 1. máj, 80. léta.

21. Praha, lidové milice, 1. máj 1985.

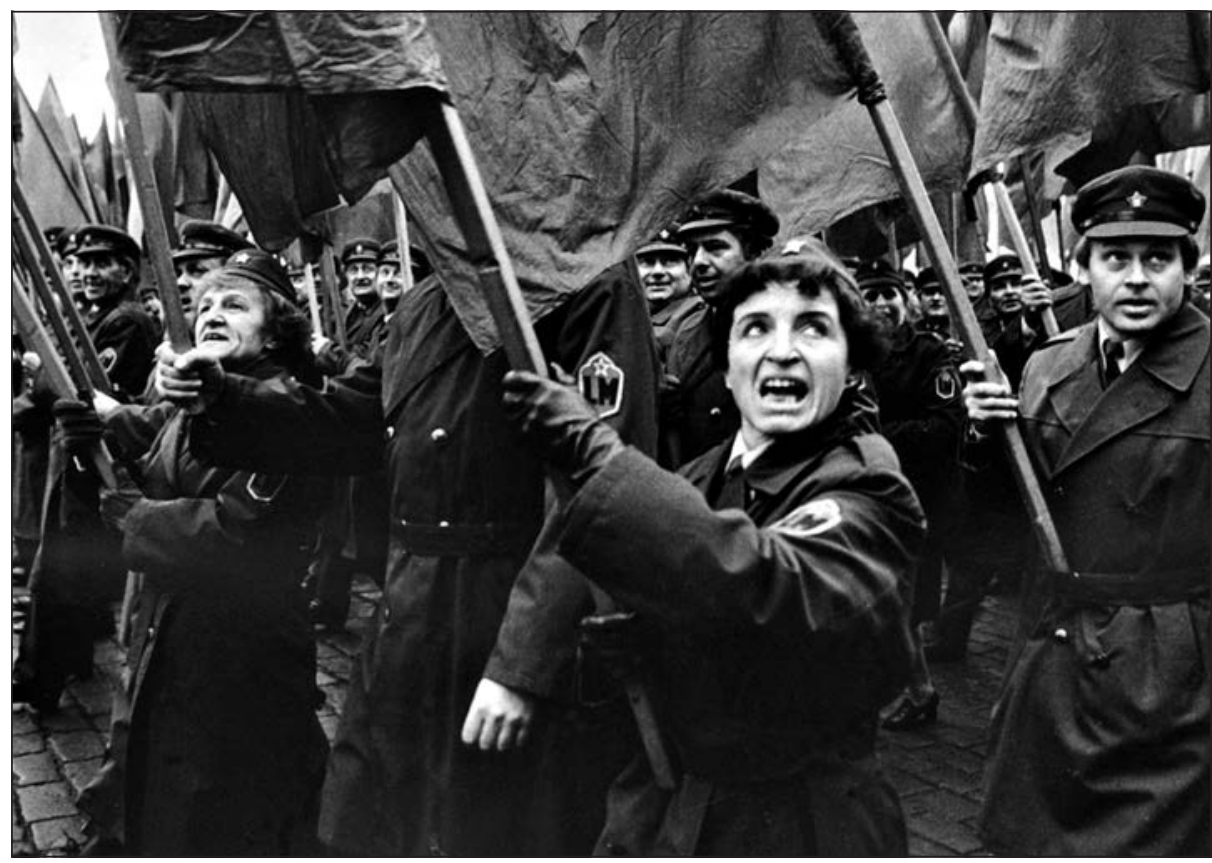




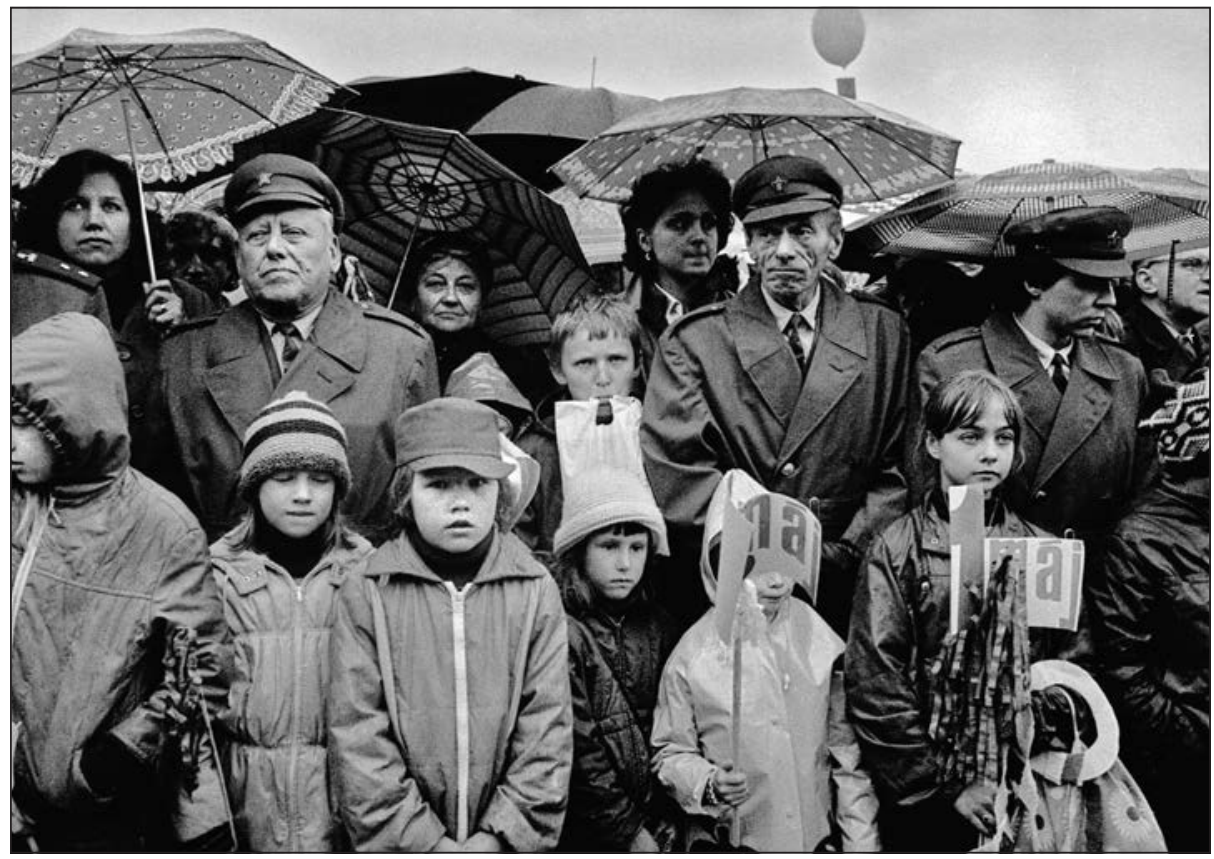

22. Praha, 1. máj 1985.

23. Praha, průvod na 1. máje, žižkovské ženy, 80. léta.

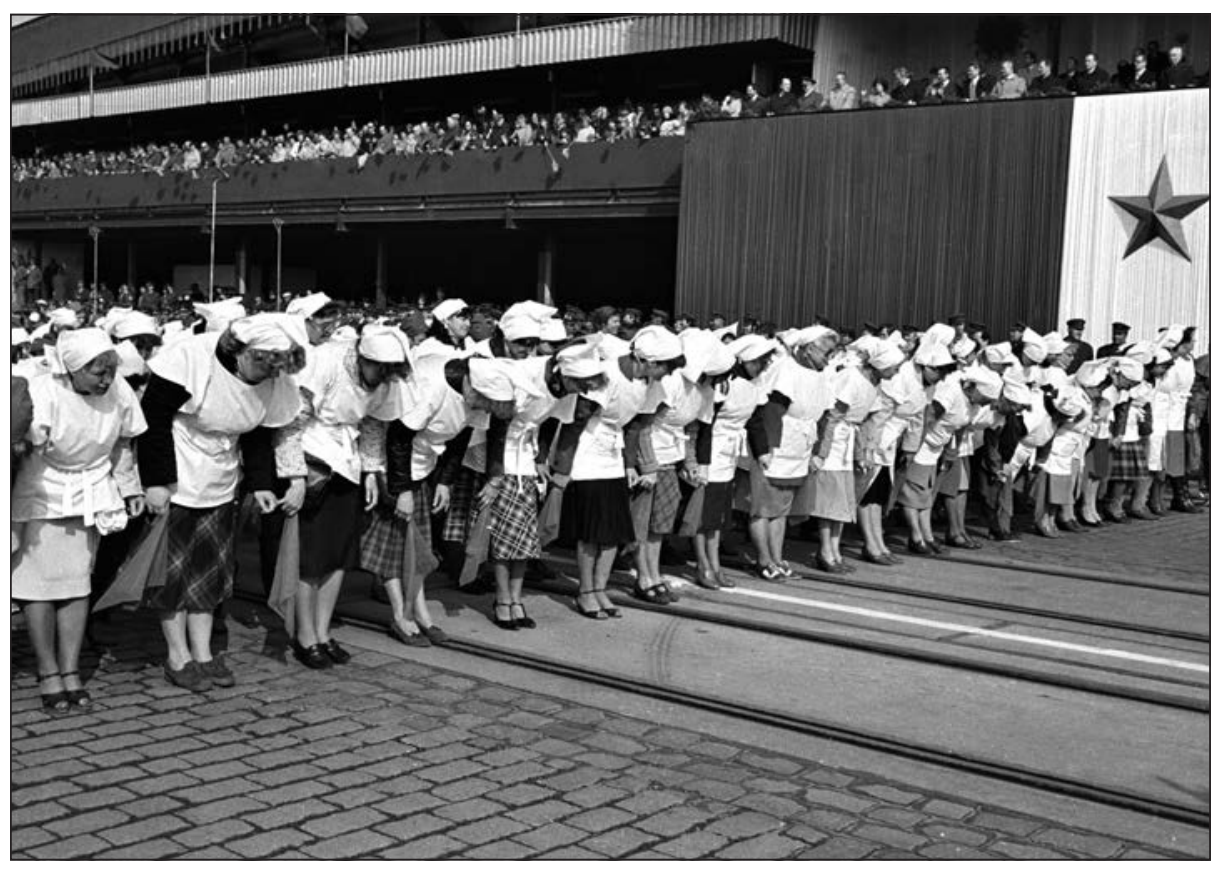




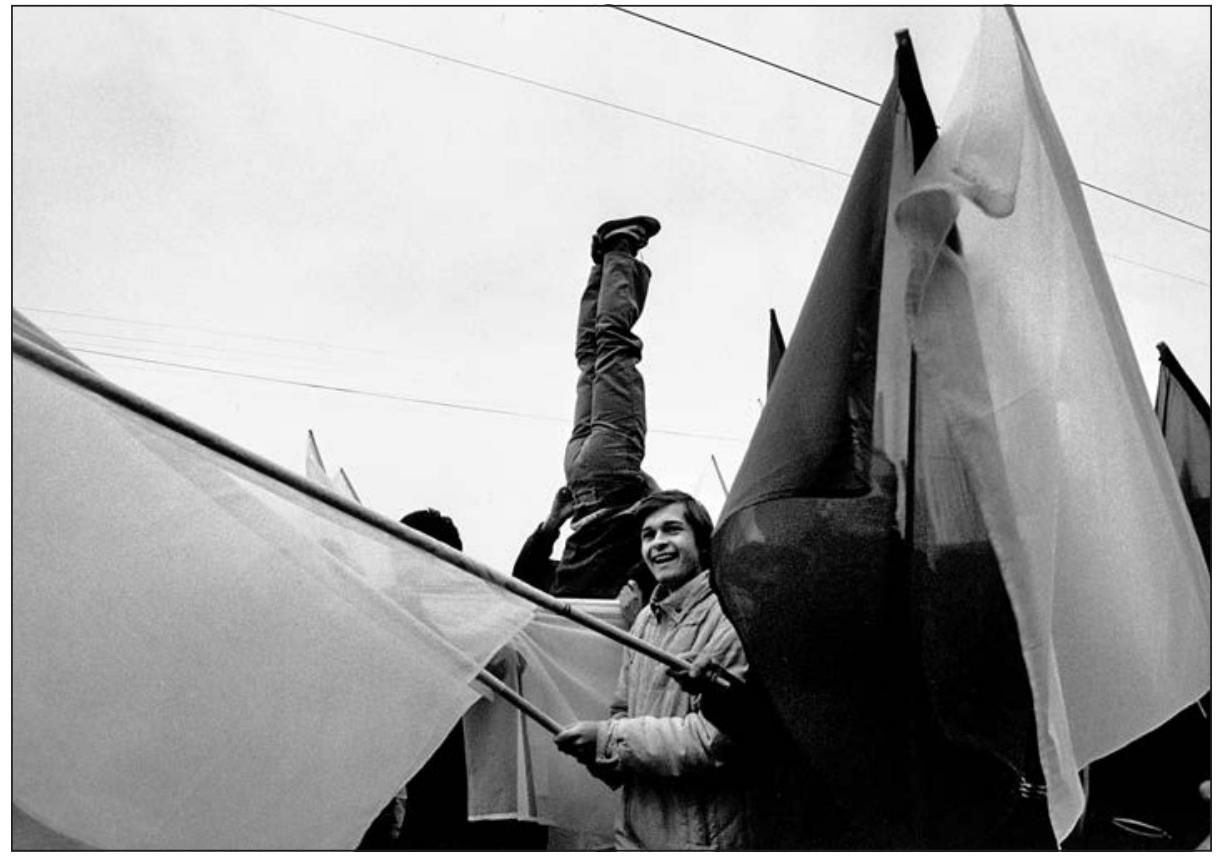

24. Praha, májová veselice, 80. léta.

\section{Praha, tři milicionáři, 80. léta.}

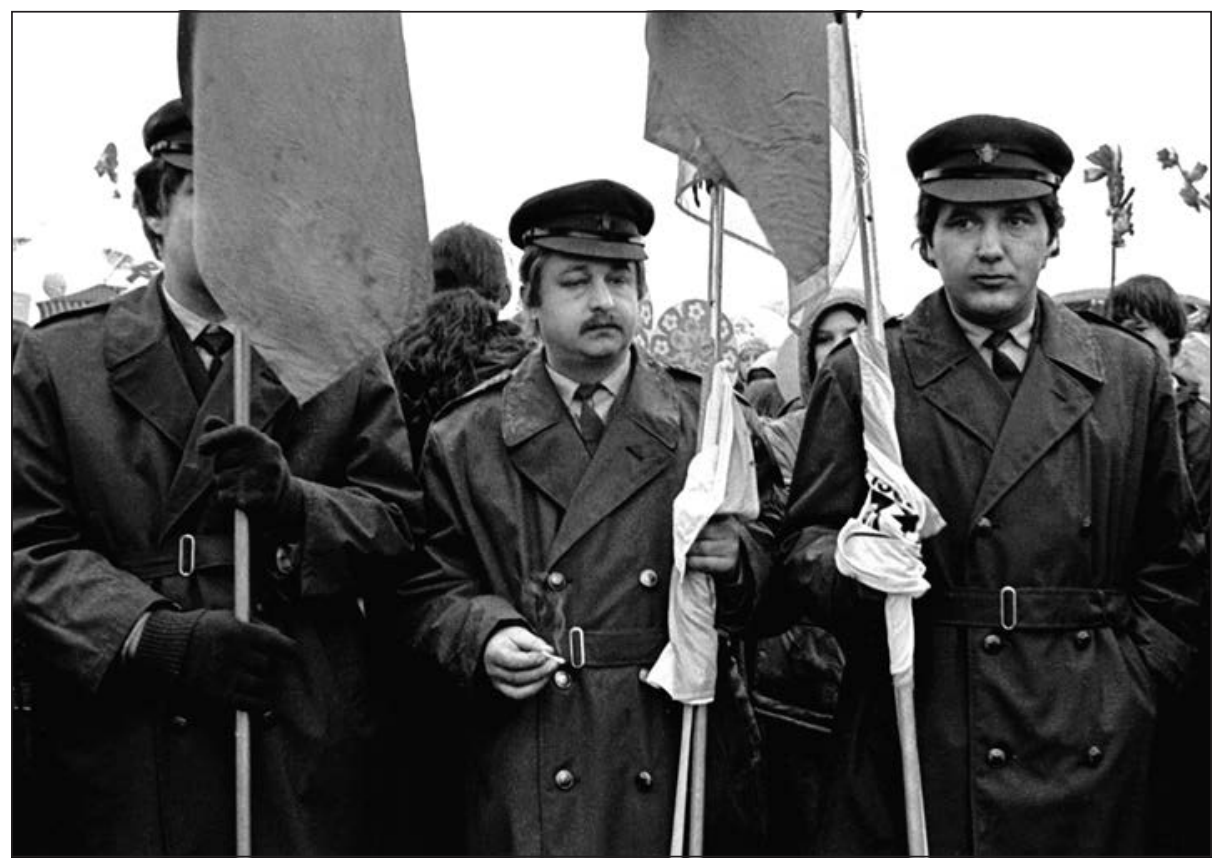




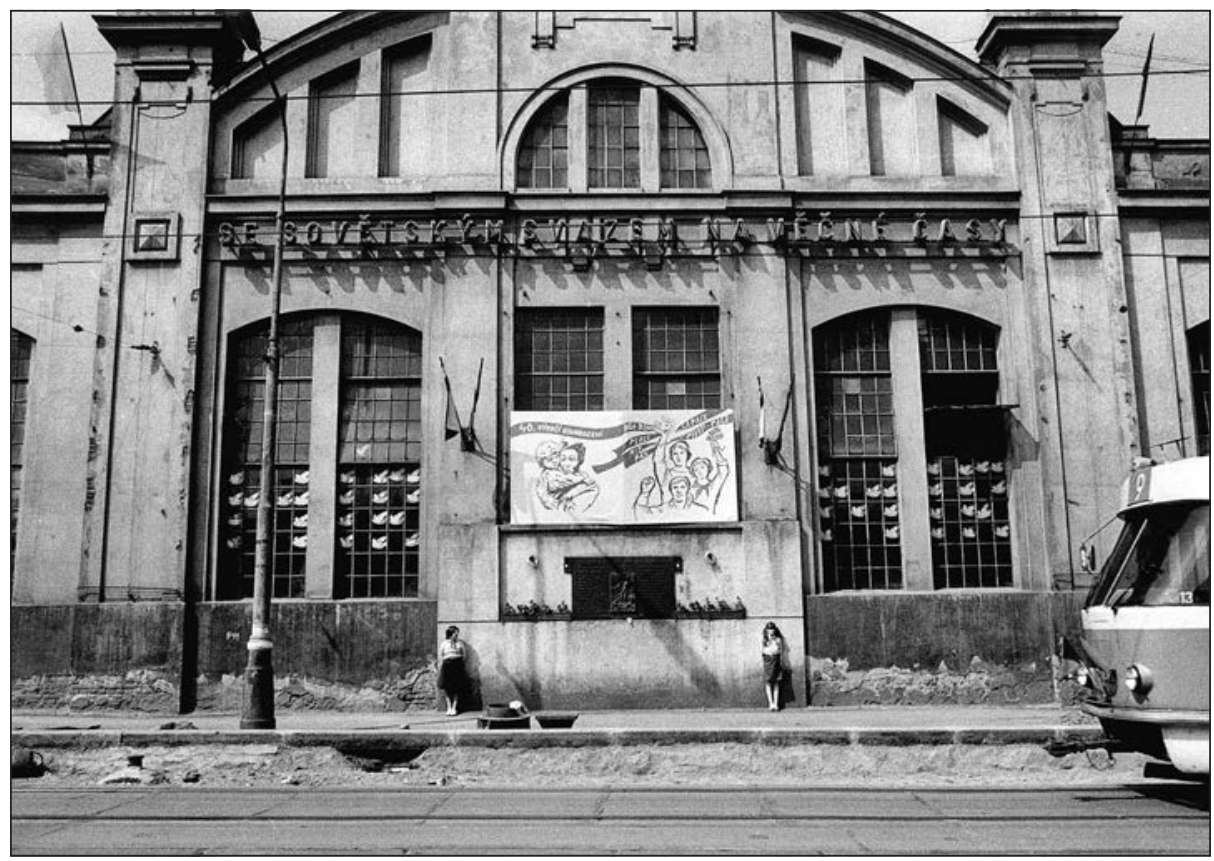

26. Praha, čestná stráž, 9. 5. 1985.

27. Praha, Staroměstské náměstí, 25. 2. 1985.

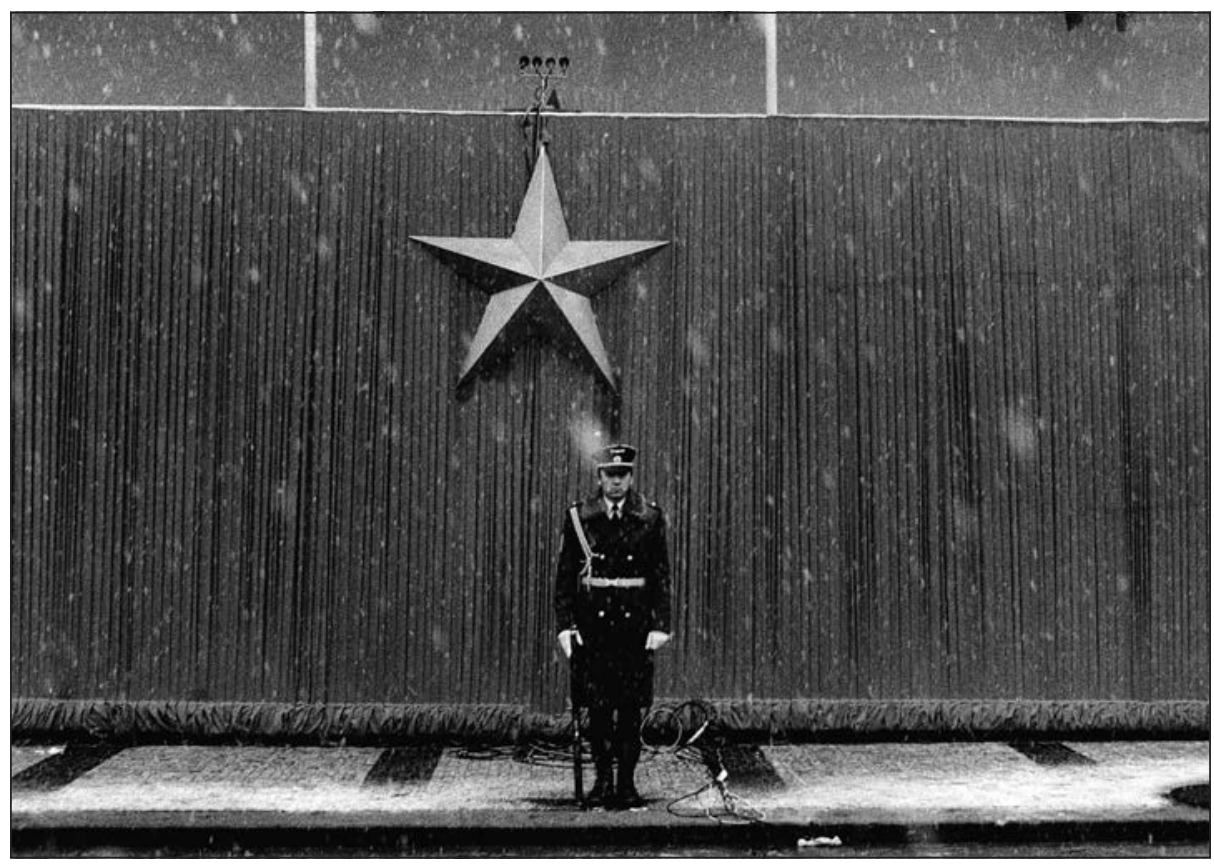




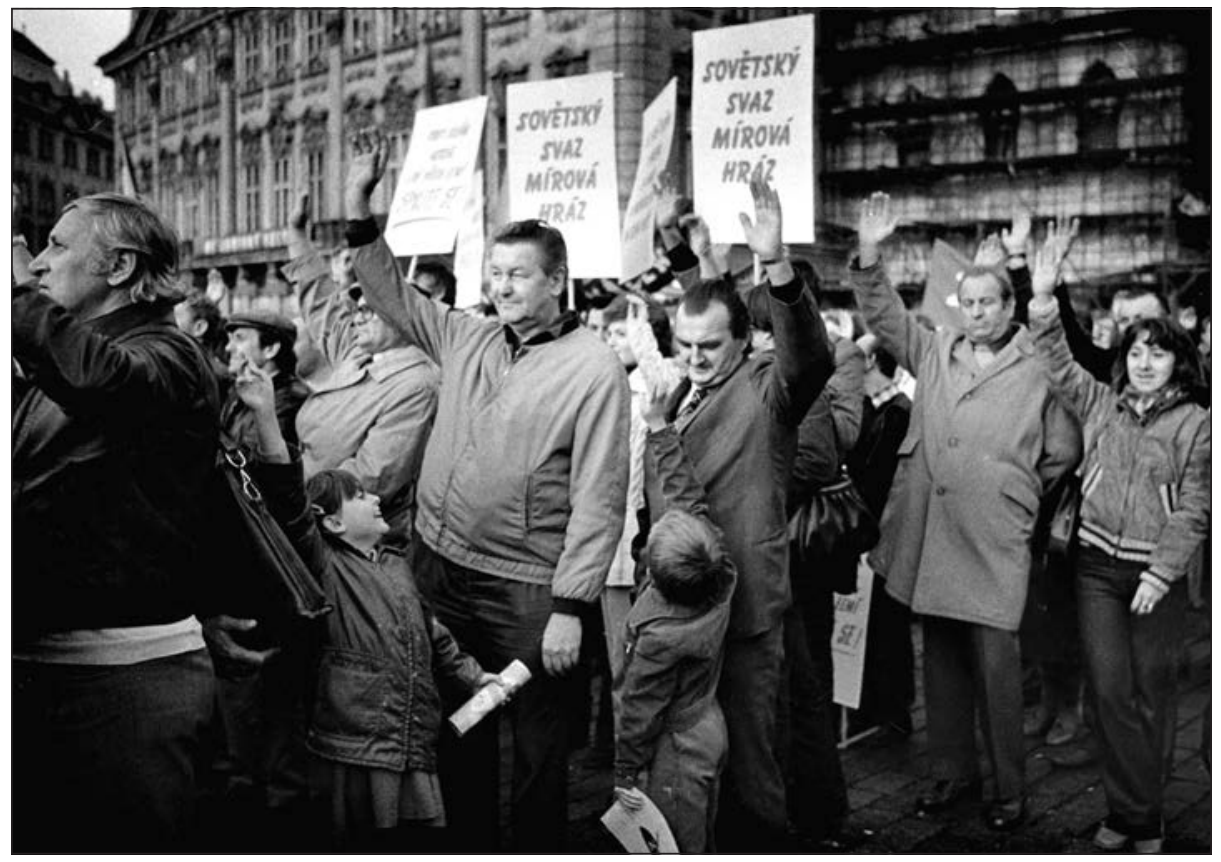

28. Praha, manifestace na Staroměstském náměstí, 80. léta.

29. Slavnost, špalír pionýrů a svazáků, 80. léta.

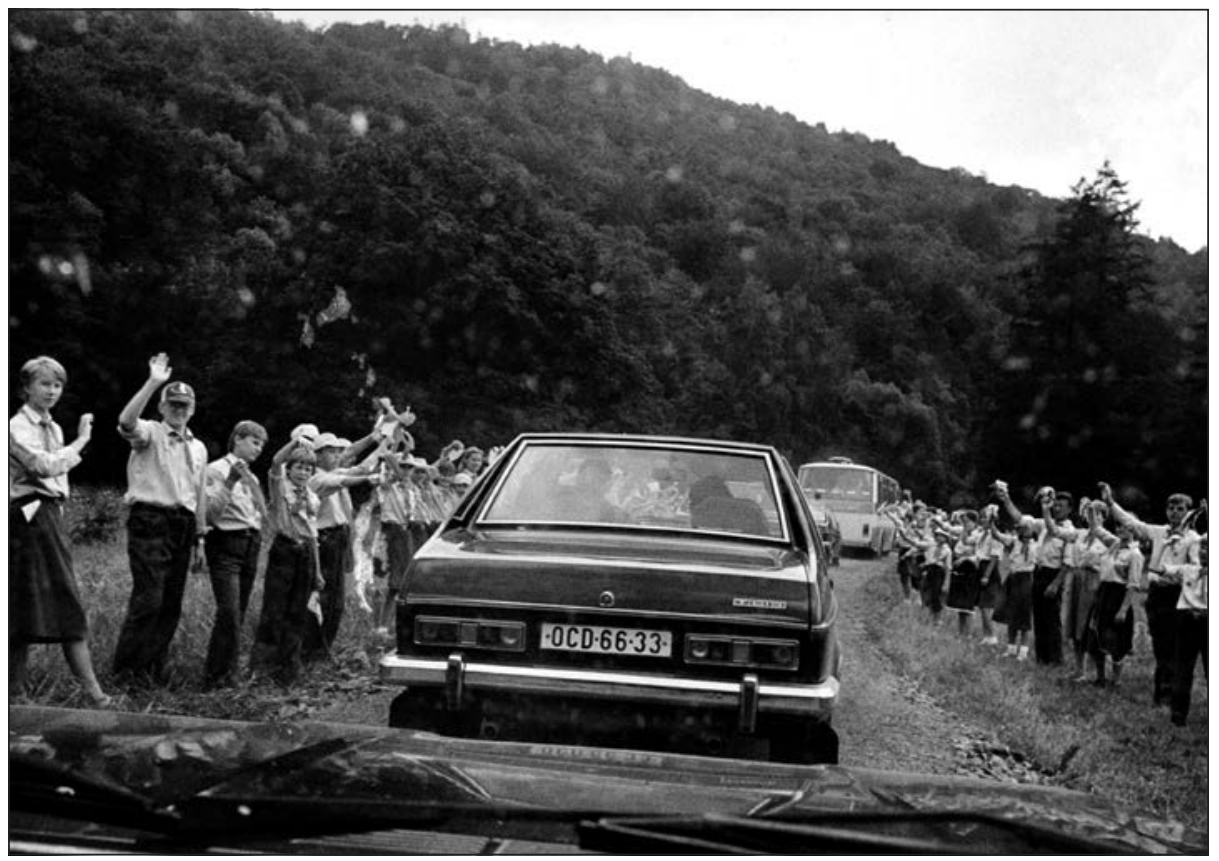




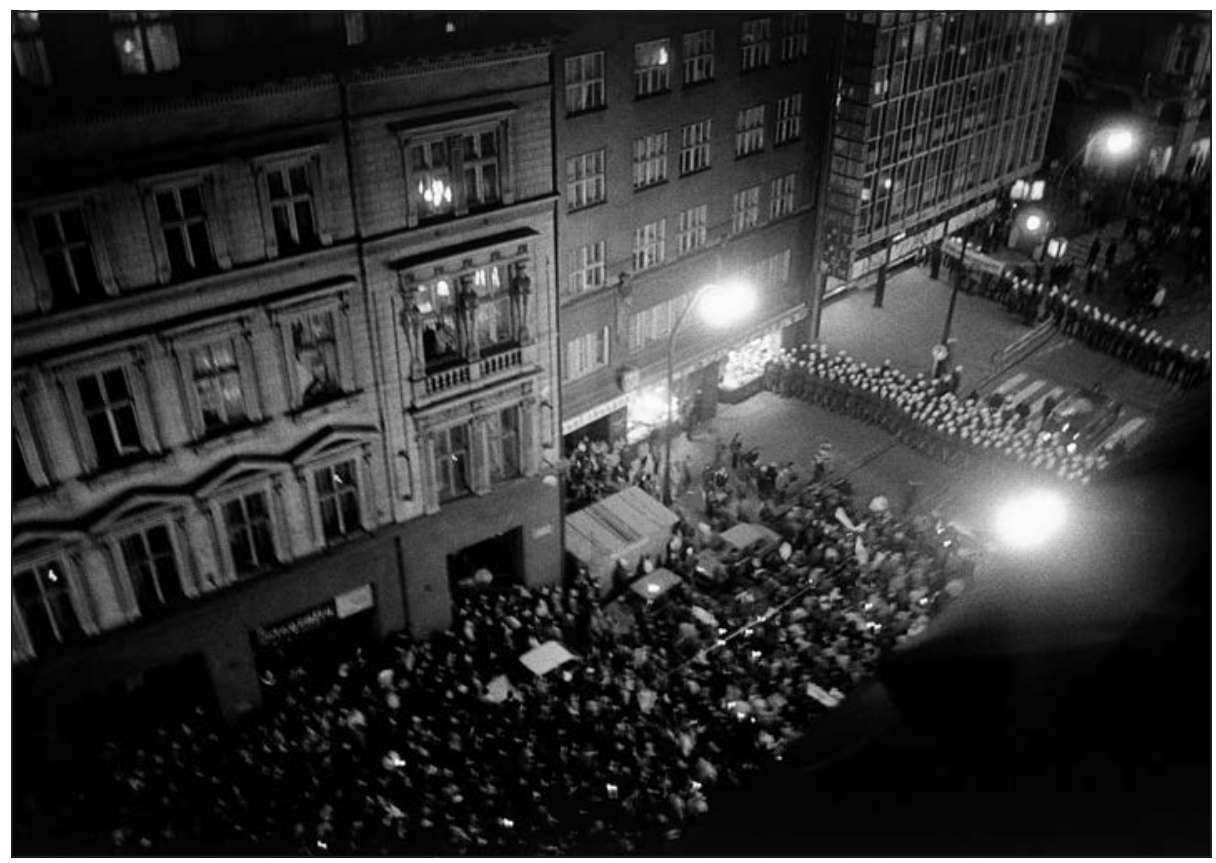

30. Praha, Národní tř́́da, konec komunismu, 17. 11. 1989.

31. Česko-slovensko-rakouská hranice, konec železné opony, leden 1990.

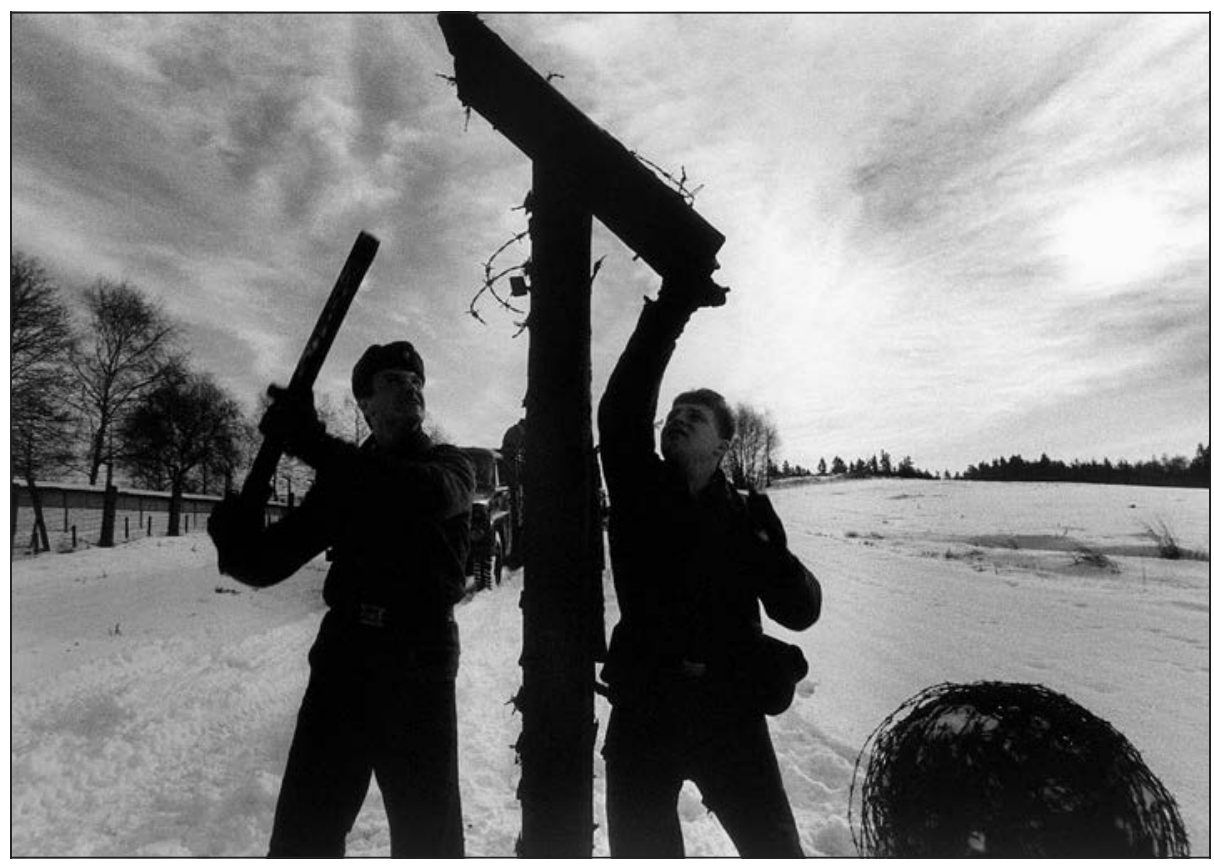

